$5-28-2021$

\title{
Book Review: Criminalizing Atrocity: The Global Spread of Criminal Laws against International Crimes
}

Verónica Michel

John Jay College of Criminal Justice-CUNY

Follow this and additional works at: https://digitalcommons.usf.edu/gsp

\section{Recommended Citation}

Michel, Verónica (2021) "Book Review: Criminalizing Atrocity: The Global Spread of Criminal Laws against International Crimes," Genocide Studies and Prevention: An International Journal: Vol. 15: Iss. 1: 137-140. DOI:

https://doi.org/10.5038/1911-9933.15.1.1825

Available at: https://digitalcommons.usf.edu/gsp/vol15/iss1/12

This Book Review is brought to you for free and open access by the Open Access Journals at Digital Commons @ University of South Florida. It has been accepted for inclusion in Genocide Studies and Prevention: An International Journal by an authorized editor of Digital Commons @ University of South Florida. For more information, please contact digitalcommons@usf.edu. 


\title{
Book Review: Criminalizing Atrocity: The Global Spread of Criminal Laws against International Crimes
}

\author{
Verónica Michel \\ John Jay College of Criminal Justice- \\ City University of New York (CUNY) \\ New York, U.S.A.
}

Criminalizing Atrocity: The Global Spread of Criminal Laws against International Crimes

Mark S. Berlin

New York, Oxford University Press, 2020

272 Pages; Price: $\$ 85.00$ Hardcover

Reviewed by Verónica Michel

John Jay College of Criminal Justice-CUNY

There is a vast literature focused on the puzzle of why similar institutions, norms, or laws are adopted in different countries. The topics that have been studied include human rights (e.g., same-sex marriage rights, voting rights), judicial reforms (e.g., constitutional courts, criminal procedure codes), and laws that criminalize behavior (e.g., domestic violence, female genital cutting, or the trafficking of persons). But to my knowledge Mark S. Berlin is the first scholar who has studied the diffusion of laws that criminalize atrocity crimes.

Atrocity law is a particularly puzzling category of law for states to incorporate as part of their own domestic law. A term coined by David J. Scheffer, atrocity law encompasses the crimes of genocide, war crimes, and crimes against humanity. ${ }^{1}$ Thus, not only the domestication of these crimes constitutes the implementation of norms first adopted in international treaties, but their incorporation into domestic criminal law increases the chances of future prosecutions against state agents in domestic jurisdictions. ${ }^{2}$ Also puzzling, Berlin notes, is that most states adopted atrocity laws before the international human rights movement prioritized individual criminal accountability for human rights violations in the 1990s. ${ }^{3}$ So lacking pressure from below, why would states introduce laws that could increase the risk of their own agents to face trial for committing atrocities? In his book, Criminalizing Atrocity: The Global Spread of Criminal Laws against International Crimes, Berlin answers this question following a carefully crafted mixed-method research design that required extensive archival research, interviews, and the construction of two impressive datasets with cross-country data on national atrocity laws and criminal code reforms.

To understand why atrocity law has been introduced in domestic criminal law, Berlin argues, we must understand how states have done so. ${ }^{4} \mathrm{~A}$ closer look the processes through which criminal law is created reveals that new offenses may be adopted through two different "pathways" that involve different actors with different motivations. First, through "targeted legislation" governments can pass a new statute or amend an existing one just to incorporate a new crime. ${ }^{5}$ Adoption of atrocity laws through targeted legislation is explained by what Berlin

\footnotetext{
${ }^{1}$ David J. Scheffer, “The Future of Atrocity Law," Suffolk Transnational Law Review 25, no. 3 (Summer 2002), $389-432$.

2 Mark S. Berlin, Criminalizing Atrocity: The Global Spread of Criminal Laws against International Crimes (New York: Oxford University Press, 2020), 11.

3 Ibid., 12.

4 Ibid., 16.

5 Ibid., 27.
}

Verónica Michel. "Book Review: Criminalizing Atrocity: The Global Spread of Criminal Laws against International Crimes." Genocide Studies and Prevention 15, no. 1, 137-140. https://doi.org/10.5038/1911-9933.15.1.1825.

(C) 2021 Genocide Studies and Prevention. 
calls the "rational expression thesis." In these instances the legislation is the product of government leaders' preferences and initiatives. ${ }^{6}$ Democracies, thus, are more likely than non-democracies to introduce atrocity laws through targeted legislation, although some may take longer than non-democracies to do so.7 Also, "false negatives" are expected, i.e., democracies that have not criminalized atrocities. The reason that democracies either take longer or do not criminalize atrocity laws, Berlin argues, is that these type of laws are a low priority for governments or they are perceived as unnecessary if the country has a monist legal system. ${ }^{8}$

The second pathway is large-scale reform, when governments decide to rewrite and replace their national criminal codes. ${ }^{9}$ Berlin found that most atrocity laws around the world have been introduced as part of major criminal code reforms, not through targeted legislation. ${ }^{10}$ Berlin argues that atrocity crimes are more likely to be incorporated through major reforms because drafting a new penal code requires technical expertise. Thus, the drafting is delegated to technocratic criminal law experts, ${ }^{11}$ which depoliticizes the legislative review and approval of the code, as the draft itself is both perceived and framed as a technical modernization of the law. ${ }^{12}$ This second pathway, Berlin argues, increases the likelihood that states adopt atrocity laws because technocratic experts are motivated to draft a "modern" code, which prompts them to seek out ideas/codes which they tend to borrow, a process he names as the "technocratic legal borrowing thesis." Berlin argues that borrowing happens through an emulation mechanism, when drafters use codes adopted in other states as models, and/or through a professionalization mechanism, when drafters are inspired by ideas promoted by transnational professional networks."13

There are many things to like about this book (some of which I mention below), but I want to highlight two features that in my opinion make this book unique. First, with this book Berlin has made an incredible empirical contribution. Before this book there was no crosscountry data on criminal code reforms or on atrocity laws. Thanks to these datasets we now know, for instance, that criminal code reform is more common than one might assume. Berlin found that " 121 states have done so at least once between 1945 and 2018, totaling 170 new codes or an average of 2.3 new criminal codes adopted per year. ${ }^{14}$ The number of states that have incorporated atrocity laws in their penal law since World War II is also quite surprising. Berlin found that "by the end of 2018, 133 states had criminal laws against genocide, 131 against war crimes, and 90 against crimes against humanity,"15 and as noted earlier, most of these crimes were introduced through criminal code reform. Thus, with these datasets Berlin brings to light a global phenomenon that was previously unknown in its scope.

And, second, the book is of great pedagogical and methodological value for social scientists. The reading of this book is interesting, enjoyable, and refreshing in great part because Berlin's writing is clear and explicit on how the methodologies he used allowed him to test and support his argument using both quantitative and qualitative data. The way Berlin threads

\footnotetext{
${ }^{6}$ Ibid., 33.

7 Monist legal systems are those where constitutions provide that ratified international treaties are automatically enforceable as domestic law. Dualist legal systems, in contrast, require the implementation of national legislation. Berlin, notes however, that "the consensus among international criminal law scholars is that the direct application of international criminal law in the absence of domestic criminal legislation is both legally and normatively problematic." See Ibid., 32.

8 Ibid., 32-33.

9 Ibid., 18.

10 Ibid., 11.

${ }^{11}$ Ibid., 38.

12 Ibid., 46-47.

${ }^{13}$ Ibid., 42-45.

14 Ibid., 34 .

15 Ibid., 85.
} 
theory, methodology, and empirics throughout the chapters make this book a great model for both students and teachers of research design, qualitative methods, and mixed methods. In particular, I highly recommend the book as an example of qualitative case selection and process tracing in the social sciences.

The book is organized in seven chapters. The first three chapters introduce the reader to the topic and provide necessary background. In the introductory chapter, Berlin describes the puzzle, provides a summary of the argument, and his mixed-method research design. In the second chapter, Berlin draws on the human rights and norm diffusion literatures to build his theoretical framework, and he details the different expectations derived from the "rational expression" and "technocratic borrowing" theses. As thorough as this chapter is in detailing the theory, the puzzle ultimately speaks to the larger question of why a particular behavior or offense is criminalized in domestic statutes, so I was surprised that Berlin did not engage with the literature focused on explaining criminalization of human behavior. I also would have also appreciated a brief explanation of how the diffusion mechanisms proposed here are different to the diffusion mechanisms normally highlighted in the literature (for instance, it is not clear how the "professionalization mechanism" is different from "socialization"). In chapter 3, Berlin offers a fascinating historical journey to trace the origins of the idea of including atrocity crimes in domestic criminal law. Berlin found that this idea originated within a group of influential European criminal law scholars, who through a professional association, the International Association of Penal Law (Association Internationale de Droit Pénal or AIDP), played a key role in spreading the idea as an important feature of a "modern" code. ${ }^{16}$ Similar to past research that has stressed the key role of experts in norm diffusion, Berlin found that over time the idea spread among criminal law scholars through professionalization and/or emulation mechanisms.

The empirical support to his arguments can be found in chapters 4 to 6 . In chapter 4 , Berlin uses an event history model to test determinants of domestic atrocity laws. The results provide overall support to his two theses, showing that from 1950 until 2013 democratic states were more likely to pass targeted legislation, and states with criminal code reform were more likely to include atrocity crimes when more regional legal peers had already done so and the state had criminal law scholars linked with AIDP. ${ }^{17}$ Quite surprisingly, an important number of countries that incorporated atrocity laws did so during the Cold War and many of those were autocracies at the time. ${ }^{18}$ These reforms, Berlin asserts, would later ease the path for future human rights prosecutions in those countries..$^{19}$ The results of the chapter are compelling and interesting. I was left only wondering why, if one potential explanation for "false negatives" is the type of legal system (monist vs. dualist), 20 this variable was not included in the models.

I found chapters 5 and 6 the most interesting, where the reader will find a great example of how to verify, through careful case selection and process tracing, the causal mechanisms of an argument. In chapter 5 Guatemala was selected as a "pathway case," 21 i.e., an example of a country that, against the odds, in the middle of a civil war enacted a new criminal code that introduced atrocity crimes in 1973. Through careful process tracing Berlin shows how drafters borrowed provisions from other codes in the region (through emulation) and from ideas supported by the AIDP (through professionalization), and because the drafting process was perceived as technical, the legislative review and approval was depoliticized. In Chapter 6 Berlin demonstrates the methodological advantage of looking at three "negative cases," i.e.,

\footnotetext{
16 Ibid., 55.

17 Ibid., $97-105$.

18 Ibid., 90.

19 Ibid., 181

20 Ibid., 32.

${ }^{21}$ Berlin defines a pathway case as "one in which both the explanatory variable and outcome of interest are present or high, yet competing explanatory variables are absent or low. In other words, the case should be 'most likely' for the theory of interest and 'least likely' for alternative theories." See Ibid., 21.
} 
cases that did not lead to atrocity criminalization against theoretical expectations, to identify the scope conditions of his thesis. In Colombia and Poland, Berlin found that sometimes, even with a criminal code reform, legislators may fear the potential implications of including atrocity provisions and decide not to include these in the final draft. In the Maldives, at the time of reform the country lacked domestic technical expertise, so the government instead hired foreign experts to draft the code. In this case atrocity crimes were not considered because the drafters did not look for models containing atrocity crimes nor they had links to the AIDP. ${ }^{22}$ And finally, in his last chapter, Berlin summarizes the book's findings and provides some implications for research on human rights accountability and international law.

In summary, this is a fantastic book. Political scientists will find that Berlin's research joins the recent wave of pathbreaking scholarship that has emerged within political science that focuses on the study of legal institutions outside constitutional courts and constitutional law. Diffusion scholars may like this complex yet elegant diffusion theory that looks into different pathways to explain different diffusion mechanisms. And human rights and legal scholars will likely enjoy the history of domestication of atrocity laws and may rethink how domestic laws impact human rights prosecutions. I am confident that Criminalizing Atrocity by Mark S. Berlin will be a welcomed addition to many bookshelves.

22 Ibid., 172. 